\title{
Analisis Kemampuan Berpikir Matematis Tingkat Tinggi Ditinjau dari Kecerdasan Emosional
}

\author{
Siti Mutmainah ${ }^{1}$, Ummi Rosyidah $^{2}$ \\ 1,2Pendidikan Matematika, Universitas Nahdlatul Ulama Lampung, \\ 1mutmainahsiti@unulampung.ac.id, ${ }^{2}$ ummirosyidah@unulampung.ac.id
}

\section{INFO ARTIKEL}

Riwayat Artikel:

Diterima: 15-09-2017

Disetujui: 13-10-2017

Kata Kunci:
Berpikir Matematis,
Tingkat Tinggi,
KECERDASAN
Emosional

\section{A. LATAR BELAKANG}

Matematika merupakan salah satu ilmu yang penting dalam proses pembelajaran di sekolah maupun di luar sekolah. Matematika adalah ilmu yang harus dipelajari pada setiap jenjang pendidikan, mulai dari pendidikan dasar hingga perguruan tinggi. Pada proses berpikir matematika, terdapat beberapa kemampuan yang perlu dikuasai, salah satunya adalah kemampuan berpikir matematis tingkat tinggi (KBMTT). Kemampuan ini perlu dan penting untuk dilatih karena terkait dengan visi pendidikan matematika yang mempunyai dua arah pengembangan, yaitu memenuhi kebutuhan masa kini dan masa yang akan datang (Menurut Sumarmo dalam Ibrahim 2011: 1).

Berdasarkan hasil studi yang dilakukan oleh Program international Science Assessment (PISA) yang mengevaluasi sistem pendidikan dari 72 negara di seluruh dunia, menunjukkan bahwa pencapaian kemampuan peserta didik di Indonesia dalam kompetensi matematika meningkat dari 375 poin di tahun 2012 menjadi 386 poin di tahun 2015.
Sedangkan berdasarkan hasil Trends in Mathematics International and Science Study (TIMSS) pada tahun 2015 didapat bahwa rerata skor yang diraih oleh peserta didik dari Indonesia sebesar 397, sedangkan rerata negara dalam peserta TIMSS sebesar 505,684. Hal tersebut menunjukkan bahwa keterampilan matematika di Indonesia harus terus ditingkatkan. Studi yang dilakukan oleh TIMSS mengukur kemampuan kognitif matematika yang terdiri dari pengetahuan, penerapan dan penalaran. Sedangkan, studi yang dilakukan oleh PISA mengukur literasi matematika yang terdiri dari kemampuan merumuskan, menerapkan dan menginterpretasikan prinsi-pprinsip matematika dalam beberapa konteks termasuk kemampuan melakukan konsep matematika dan menerapkan konsep matematika, prosedur, fakta-fakta, menjelaskan dan mengukur beberapa fenomena. Pada dasarnya, kedua studi tersebut menekankan penalaran matematika dan pemecahan masalah matematis, yang berkaitan dengan kemampuan menerapkan, menganalisis dan mengevaluasi masalahmasalah matematika dengan 
menggunakan strategi yang tepat. Kemampuankemampuan tersebut merupakan komponan dari KBMTT. Rendahnya KBMTT peserta didik Indonesia dapat disebabkan oleh berbagai sumber. Misalkan, proses pembelajaran matematika di Indonesia masih berfokus pada pengembangan kemampuan berpikir yang bersifat prosedural dan pembelajaran matematika belum berfokus pada pengembangan penalaran matematik peserta didik. Proses pembelajaran tersebut diawali dengan pendidik yang melakukan proses pembelajaran kepada peserta didik. Selanjutnya perlu dilakukan analisis tentang KBMTT calon pendidik, sehingga pada akhirnya keseluruhan proses pembelajaran KBMTT dapat dilakukan dengan baik oleh pendidik.

Selain itu, pada proses pembelajaran matematika terdapat hal yang penting tetapi kadang terlupakan yakni aspek afektif. Pembelajaran matematika tidak hanya mengandung aspek kognitif saja, akan tetapi terdapat juga aspek afektif, misalnya kecerdasan emosional. Hal ini cukup beralasan, karena matematika adalah suatu mata pelajaran yang sering kali dianggap sebagai mata pelajaran yang sulit. Oleh karena itu, penelitian ini bertujuan untuk menganalisis KBMTT calon pendidik ditinjau berdasarkan kecerdasan emosional.

\section{B. METODE PENELITIAN}

Jenis penelitian yang digunakan dalam penelitian ini adalah penelitian kualitatif. Penelitian ini dilakukan di Universitas Nahdlatul Ulama Lampung, pada program studi pendidikan matematika, semester IV. Teknik pengambilan sampel dilakukan dengan snowball sampling dimana pengambilan sampel dilakukan secara bergulir sampai tidak ditemukan data baru lagi baik dari informan yang lama maupun yang baru.

Pengumpulan data dilakukan setelah menentukan subjek penelitian yang memenuhi kriteria. Teknik pengumpulan data yang digunakan dalam penelitian ini yaitu think aloud method dimana mahasiswa diminta untuk mengungkapkan ekspresi verbal tentang ide yang dipikirkan ketika mengerjakan soal-soal KBMTT. Selanjutnya data dianalisis dan dilakukan validasi menggunakan triangulasi waktu. Data hasil triangulasi yang sama merupakan data subjek yang valid. Berdasarkan teknik pengambilan sampel dan pengumpulan data tersebut telah diwawancarai 12 subjek. Diperoleh sebanyak 2 orang dengan kecerdasan emosional rendah, 7 orang dengan kecerdasan emosional sedang, dan 3 orang dengan kecerdasan emosional tinggi.

Beberapa instrumen tes yang digunakan pada penelitian ini akan disajikan pada tabel 1 .

\section{TABEL 1}

INSTRUMEN TES KEMAMPUAN BERPIKIR MATEMATIS TINGKAT TINGGI (KBMTT)

\begin{tabular}{llcc}
\hline \multicolumn{1}{l}{ Indikator KBMTT } & \multicolumn{1}{c}{ Soal } & $\begin{array}{c}\text { No. } \\
\text { Soal }\end{array}$ \\
\hline $\begin{array}{l}\text { Membuktikan } \\
\text { berdasarkan fakta }\end{array}$ & $\begin{array}{l}\text { Buktikan } \\
(n-1) n\left(n^{3}+\right.\end{array}$ & bahwa & 1 \\
yang tersedia atau & $\begin{array}{l}\text { 1) senantiasa habis dibagi } \\
\text { fakta } \\
\text { dimanipulasi yang }\end{array}$ & $\begin{array}{l}\text { dengan 6 untuk semua } \\
\text { bilangan asli } n \text {. }\end{array}$ \\
\hline $\begin{array}{l}\text { Mengenali dan } \\
\text { memanfaatkan }\end{array}$ & $\begin{array}{l}\text { Tentukan bilangan asli } n \\
\text { terkecil sehingga jumlah }\end{array}$ & \\
hubungan antar ide & $\begin{array}{l}\text { ukuran sudut-sudut segi- } \\
\text { matematis }\end{array}$ & $\begin{array}{l}n, n>6 \text { kurang dari } n^{2} \\
\text { derajat! }\end{array}$ \\
\end{tabular}

Instrumen tes yang digunakan dibuat dengan mengacu pada indikator-indikator KBMTT. Indikatorindikator tersebut disajikan pada tabel 2 .

TABEL 2

INDIKATOR-INDIKATOR KEMAMPUAN BERPIKIR MATEMATIS TINGKAT TINGGI (KBMTT)

\begin{tabular}{ll}
\hline No. & \multicolumn{1}{c}{ Indikator-indikator KBMTT } \\
\hline 1 & Mengajukan argumentasi berdasarkan fakta \\
\hline 2 & $\begin{array}{l}\text { Membuktikan berdasarkan fakta yang tersedia } \\
\text { atau fakta yang dimanipulasi }\end{array}$ \\
\hline 3 & Membuat dan menyelidiki konjektur \\
\hline 4 & $\begin{array}{l}\text { Menganalisa dan menilai pemikiran atau strategi } \\
\text { matematis orang lain }\end{array}$ \\
\hline 5 & $\begin{array}{l}\text { Mengenali dan memanfaatkan hubungan antar ide } \\
\text { matematis }\end{array}$ \\
\hline 6 & Menyelesaikan masalah matematis tidak rutin \\
\hline
\end{tabular}

Penelitian ini menggunakan pengkategorian kecerdasan emosional. Pengkategorian kecerdasan menggunakan instrumen yang dikembangkan oleh Mutmainah (2015). Pengkategorian kecerdasan emosional dibagi menjadi tiga, yakni: kecerdasan emosional rendah, kecerdasan emosional sedang, dan kecerdasan emosional tinggi. setelah diberikan instrumen kecerdasan emosional, kemudian dhitung menggunakan pengkatogian sesuai dengan tabel 3.

TABEL 3

PENGKATEGORIAN KECERDASAN EMOSIONAL

\begin{tabular}{lc}
\hline \multicolumn{1}{c}{ Kategori } & Rentang Skor \\
\hline Kecerdasan emosional tinggi & $b_{j}>\bar{b}+\frac{1}{2} s$ \\
\hline Kecerdasan emosional sedang & $\bar{b}-\frac{1}{2} s \leq b_{j} \leq \bar{b}+\frac{1}{2} s$ \\
\hline Kecerdasan emosional rendah & $b_{j}<\bar{b}-\frac{1}{2} s$ \\
\hline
\end{tabular}

Keterangan : 
$b_{j}$ : Skor kecerdasan emosional peserta didik .

$\bar{b}$ : Rerata dari seluruh skor kecerdasan emosional peserta didik.

$s \quad$ : Standar deviasi skor kecerdasan emosional peserta didik.

\section{HASIL DAN PEMBAHASAN}

Terdapat 6 indikator KBMTT dan terdapat 3 pengkategorian kecerdasan emosional. Berdasarkan hasil penelitian ini menunjukkan bahwa terdapat perbedaan deskripsi dari masingmasing kategori kecerdasan emosional. Subjek dengan tingkat kecerdasan emosional tinggi mampu memberikan jawaban yang sesuai dengan jawaban soal pada beberapa indikator, sedangkan pada kategori sedang dan rendah hanya sedikit memberikan jawaban yang sesuai.

\section{Subjek IS dengan Kategori Kecerdasan Emosional Tinggi}

Subjek IS merupakan salah satu subjek dengan kategori kecerdasan emosional tinggi. Hasil yang diperoleh subjek IS dalam mengerjakan soal KBMTT adalah 71. Hasil tersebut menunjukkan KBMTT yang baik. Subjek IS mampu mengerjakan soal tes dengan baik, walaupun pada soal tes nomor 1 belum terselesaikan seluruhnya. Subjek mampu menulis apa saja yang diketahui dari soal, merumuskan penyelesaian dengan baik dan memberikan solusi penyelesaian yang runtut dan teliti. Subjek IS juga melakukan proses perhitungan yang teliti sehingga meminimalisir kesalahan dalam proses menghitung jawaban soal tes KBMTT. Subjek IS mampu mengaitkan konsep pertidaksamaan dengan konsep pencarian akar menggunakan rumus abc (mengaitkan konsep satu dengan konsep yang lain). Contoh alternatif penyelesaian yang dilakukan pada indikator membuktikan berdasarkan fakta yang tersedia atau fakta yang dimanipulasi. Seperti gambar $1 \mathrm{di}$ bawah ini:

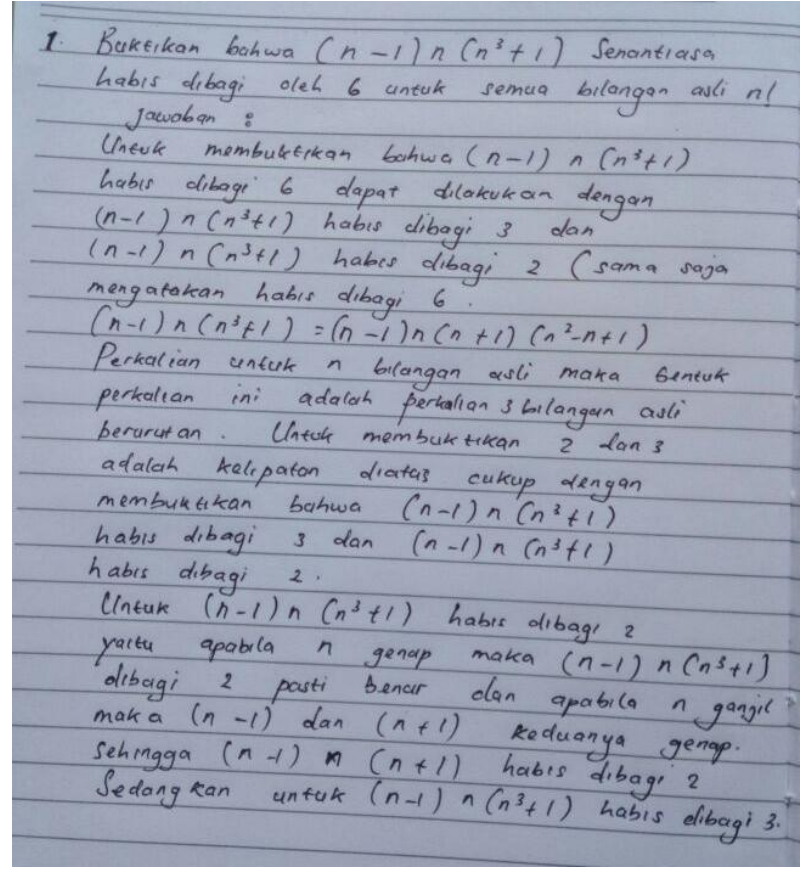

Gambar 1. Alternatif Penyelesaian Soal Nomor 1 Subjek IS

Alternatif penyelesaian yang dilakukan pada indikator mengenali dan memanfaatkan hubungan antar ide matematis. Seperti gambar 2 di bawah ini:

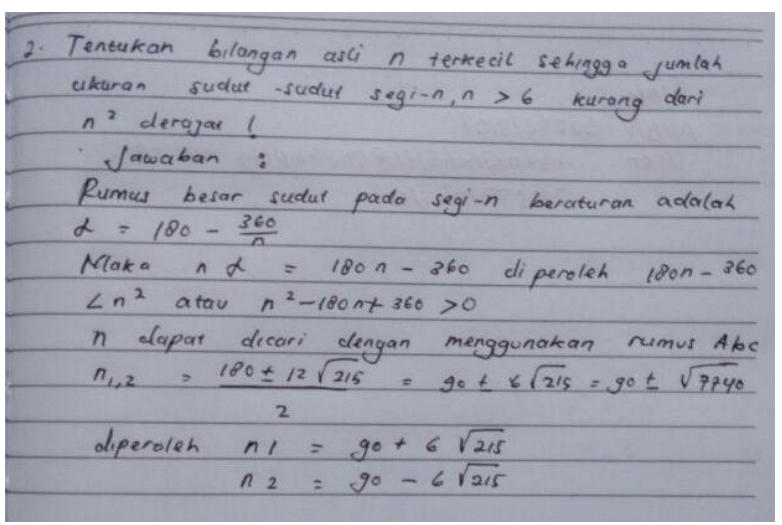

Gambar 2. Alternatif Penyelesaian Soal Nomor 2 Subjek IS

Berdasarkan hasil alternatif penyelesaian soal tes KBMTT, terlihat bahwa subjek IS dengan kategori kecerdasan emosional tinggi memiliki kemampuan menyelesaian soal tes KBMTT yang baik. Hasil tersebut juga sesuai dengan hasil penelitian yang dilakukan oleh Abdullah et al,. (2004) dalam penelitiannya juga menunjukkan bahwa pada peserta didik dengan tingkatan emosional yang tinggi dan kemampuan dalam mengatur emosinya bertanggung jawab terhadap tugas-tugas akademik dan cenderung lebih baik dalam tes yang sedang dihadapinya. Senada dengan hal tersebut hasil penelitian yang dilakukan oleh Nwadinigwe dan Azuka (2012) 
yang menyatakan bahwa terdapat hubungan yang signifikan antara kecerdasan emosional dengan prestasi akademik dimana tingkatan kecerdasan emosional seseorang berpengaruh terhadap kemampuan akademiknya. Selain itu, hasil penelitian yang dilakukan oleh Hanifa juga menunjukkan bahwa peserta didik dengan tingkat kecerdasan emosional tinggi menghasilkan prestasi belajar yang lebih baik daripada peserta didik dengan tingkat kecerdasan emosional sedang dan rendah serta peserta didik dengan tingkat kecerdasan emosional sedang menghasilkan prestasi belajar yang lebih baik daripada peserta didik dengan tingkat kecerdasan emosional rendah.

\section{Subjek M dengan Kategori Kecerdasan Emosional Sedang}

Subjek M merupakan salah satu subjek dengan kategori kecerdasan emosional sedang. Hasil yang diperoleh subjek $M$ dalam mengerjakan soal KBMTT adalah 60. Hasil tersebut menunjukkan KBMTT yang cukup baik. Subjek M mampu mengerjakan soal tes dengan cukup baik, walaupun pada soal tes nomor 1 dan 2 belum dapat terselesaikan seluruhnya. Subjek M kurang mampu merumuskan penyelesaian dengan memanfaatkan konsep-konsep matematika yg lain. Sehingga soal tersebut belum dapat terselesaikan. Subjek M sudah mampu menguraikan sifat dasar dari aljabar, kemudian menemukan konsep bahwa jika suatu bilangan dapat habis dibagi dengan 6 (bilangan genap) maka bilangan tersebut adalah bilangan genap juga. Alternatif jawaban subjek M, sebagai berikut:

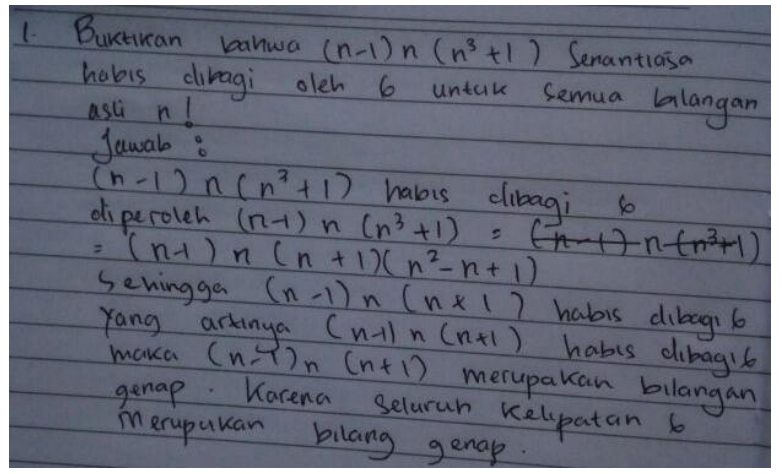

Gambar 3. Alternatif Penyelesaian Soal Nomor 1 Subjek M

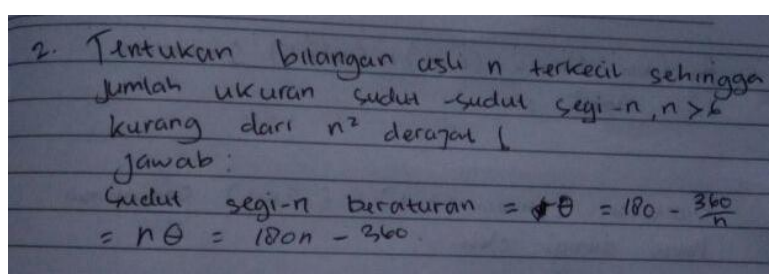

Gambar 4. Alternatif Penyelesaian Soal Nomor 2 Subjek M

Berdasarkan alternatif penyelesaian soal tes KBMTT, terlihat bahwa subjek M dengan kategori kecerdasan emosional sedang memiliki kemampuan menyelesaikan soal dengan cukup baik, namun belum terselesaikan secara maksimal.

\section{Subjek RN dengan Kategori Kecerdasan Emosional Rendah}

Subjek RN merupakan salah satu subjek dengan kategori kecerdasan emosional rendah. Hasil yang diperoleh subjek RN dalam mengerjakan soal KBMTT adalah 35. Hasil tersebut menunjukkan KBMTT yang kurang baik.

\section{SIMPULAN DAN SARAN}

Berdasarkan hasil analisis data, diperoleh kesimpulan sebagai berikut. Kemampuan Berpikir Matematis Tingkat Tinggi (KBMTT) mahasiswa pendidikan matematika Universitas Nahdlatul Ulama Lampung dengan kategori kecerdasan emosional tinggi, sedang, dan rendah. Subjek dengan kecerdasan emosional tinggi memiliki KBMTT yang baik, dan jelas lebih baik dari KBMTT subjek dengan kategori sedang dan sedang. Sedangkan subjek dengan kecerdasan emosional sedang memiliki KBMTT yang cukup baik atau dengan kata lain lebih baik dari subjek yang memiliki kecerdasan emosional rendah.

\section{UCAPAN TERIMA KASIH}

Penulis mengucapkan terimakasih kepada Dr. Nasir. selaku Rektor Universitas Nahdlatul Ulama Lampung yang selalu memberikan bimbingan, masukkan, dan motivasi kepada penulis. Serta memberikan kesempatan kepada penulis untuk melakukan penelitian di lingkungan kampus Universitas Nahdlatul Ulama Lampung. Untuk Ibu tercinta yang selalu memberikan doa dan semangat sehingga penelitian ini dapat terselesaikan dengan baik.

\section{REFERENSI}

[1] Abdullah, M.E, Elias, H.,Mahyuddin, R. and Uli, J. (2004). Emotional Intelligence and Academic Achievement among Malaysian Secondary Student. 
74 | JTAM, Vol. 1, No. 1, Oktober 2017, Hal. 70-74

Pakistan Journal of Psychological Research, 19(4), 105121

[2] Arends, R.I. (2008). Learning to Teach: Belajar untuk Mengajar. Edisi Ketujuh. Buku Dua. Yogyakarta: Pustaka Pelajar

[3] Ibrahim. (2011). Analisis Kemampuan Berpikir Matematis Tingkat Tinggi dan Kecerdasan Emosional Siswa Madrasah Aliyah di Kota Yogyakarta. Laporan Penelitian Pengembangan Ilmu

[4] Martin, M.O. \& Mullis. (2011). Relationships Among Reading, Mathematics, and Science Achievement at the Fourth Grade-Implications for Early Learning. Boston: TIMSS and PIRLS International Study Center.

[5] Mutmainah, Siti. (2015). Eksperimentasi Model Problem Based Learning (PBL) dan Group Investigation (GI) Ditinjau Dari Kategori Kecerdasan Emosional Peserta Didik Terhadap Kemampuan Berpikir Matematis Tingkat Tinggi Kelas VII SMP Negeri Se-Kabupaten Sragen Tahun Pelajaran 2014/2015. Tesis UNS. Surakarta: Tidak diterbitkan.

[6] Nwadinigwe, I.P. and Obieke, A.U. (2012). The Impact of Emotional Intelligence on Academic Achievement of Senior Secondary School Students in Lagos, Nigeria. Journal of Emerging Trends in Educational Research and Policy Studies (JETERAPS), 3(4), 395-401 